\title{
Curcumin suppresses tumor necrosis factor- $\alpha$-induced matrix metalloproteinase-2 expression and activity in rat vascular smooth muscle cells via the NF-кB pathway
}

\author{
YI ZHONG $^{1^{*}}$, WENYAN YU $^{2 *}$, JIAN FENG $^{1}$, ZHONGCAI FAN $^{1}$ and JIAFU LI ${ }^{1}$ \\ ${ }^{1}$ Department of Cardiology, The Affiliated Hospital of Luzhou Medical College, Luzhou, Sichuan 646000; \\ ${ }^{2}$ Department of Pathophysiology, Southern Medical University, Guangzhou, Guangdong 510515, P.R. China
}

Received December 9, 2013; Accepted March 18, 2014

DOI: $10.3892 /$ etm.2014.1647

\begin{abstract}
The aim of the present study was to investigate the inhibitory effect of curcumin on tumor necrosis factor (TNF)- $\alpha$-induced cell migration and matrix metalloproteinase (MMP)-2 expression and activity in rat vascular smooth muscle cells (VSMCs), in order to identify whether the effects are mediated by the nuclear factor (NF) $-\kappa B$ signaling pathway. The VSMCs cells were pretreated with curcumin prior to stimulation with TNF- $\alpha$. Reverse transcription-polymerase chain reaction and western blot analysis were used to determine the MMP-2 mRNA and protein expression levels in TNF- $\alpha$-stimulated VSMCs. Activity levels of MMP-2 were measured using a gelatin zymography assay. Intracellular reactive oxygen species (ROS) generation was also analyzed. Curcumin was found to suppress the TNF- $\alpha$-stimulated migration of VSMCs. In addition, curcumin inhibited the TNF- $\alpha$-induced induction of MMP-2 activity and expression. Curcumin also decreased ROS generation in TNF- $\alpha$-stimulated VSMCs. Signal transduction experiments indicated that TNF- $\alpha$-induced MMP-2 expression in VSMCs was partly reversed with the application of an NF- $\mathrm{NB}$ inhibitor (BAY11-7082). In addition, western blot analysis revealed that curcumin reduced $\mathrm{NF}-\kappa \mathrm{B}$ p 65 protein expression in TNF- $\alpha$-stimulated VSMCs at the concentration of 20 and $40 \mu \mathrm{M}$. Therefore, these observations indicated that curcumin suppressed TNF- $\alpha$-stimulated VSMC migration and partially prevented TNF- $\alpha$-induced MMP-2 expression and activity in VSMCs via the NF- $\kappa \mathrm{B}$ pathway.
\end{abstract}

Correspondence to: Dr Yi Zhong, Department of Cardiology, The Affiliated Hospital of Luzhou Medical College, 25 Tai Ping Street, Luzhou, Sichuan 646000, P.R. China

E-mail: zhongyi1982529@163.com

*Contributed equally

Key words: curcumin, tumor necrosis factor- $\alpha$, nuclear factor- $\kappa \mathrm{B}$, matrix metalloproteinase-2

\section{Introduction}

The proliferation and migration of vascular smooth muscle cells (VSMCs) may play a key role in the development of intimal thickening following arterial-wall injury or in atherosclerosis (1). Matrix metalloproteinases (MMPs) are a broad family of zinc-dependent proteinases, which are implicated in extracellular matrix turnover, vascular wall remodeling, angiogenesis and atherosclerosis (2). Among the MMP family, several lines of evidence have hypothesized that MMP-2 plays a key role in promoting VSMC proliferation, migration and the weakening of atherosclerotic plaque stability (3). In addition, MMP-2 expression in VSMCs has been associated with a variety of pathological situations, particularly in atherosclerotic plaques, which show significantly increased MMP-2 expression and activation levels, most prominently in vulnerable regions, indicating a pathogenic role for MMP-2 in the progression of atherosclerosis $(4,5)$. Curcumin (diferuloylmethane), a bioactive constituent from Curcuma longa, possesses marked anti-inflammatory, antioxidant and anticarcinogenic properties $(6,7)$. A previous study has shown that curcumin possesses anti-inflammatory, antioxidant, anticancer, antibacterial and antiviral activities, and exhibits a strong potency in inhibiting transcription factors, protein kinases, cytokines, adhesion molecules and oxidative stress (8). In the present study, the inhibitory effect of curcumin on tumor necrosis factor (TNF)- $\alpha$-induced VSMC migration and MMP-2 expression and activity was investigated, with the aim of identifying the pathways involved.

\section{Materials and methods}

Cell culture and treatment. Rat aortic smooth muscle cells were isolated from male Sprague-Dawley rats (purchased from the laboratory animal center of Southern Medical University, Guangzhou, China), as described previously (9). The cells were cultured in Dulbecco's modified Eagle's medium (Gibco-BRL, Carlsbad, CA, USA) supplemented with $10 \%$ fetal bovine serum (Gibco-BRL), $25 \mathrm{mM}$ HEPES, $100 \mathrm{U} / \mathrm{ml}$ penicillin and $100 \mu \mathrm{g} / \mathrm{ml}$ streptomycin at $37^{\circ} \mathrm{C}$. Cells that had grown to $80-90 \%$ confluence were used for all the experiments. Cells were placed in serum-free medium for $24 \mathrm{~h}$ prior to treat- 
ment with TNF- $\alpha$ (Sigma, St. Louis, MO, USA). The study was conducted in strict accordance with the recommendations in the Guide for the Care and Use of Laboratory Animals of the National Institutes of Health. Prior to the addition of TNF- $\alpha$ to the medium, the cells were pretreated with curcumin (Solon, $\mathrm{OH}$, USA). The study was approved by the Ethics Committee of Southern Medical University.

Cell viability assay. Cells were plated with a variety of concentrations of curcumin $(0-40 \mu \mathrm{M})$ in 96 -well microtiter plates, and were then cultured for $24 \mathrm{~h}$ at $37^{\circ} \mathrm{C}$ in a $5 \% \mathrm{CO}_{2}$ incubator. Cell viability was determined using the conventional methylthiazolyl tetrazolium (MTT) reduction assay. Following the treatment of the cells with curcumin, MTT solution was added (final concentration, $5 \mathrm{mg} / \mathrm{ml}$ ) and incubation was continued for $4 \mathrm{~h}$ at $37^{\circ} \mathrm{C}$. The dark blue formazan crystals formed in the intact cells were solubilized with dimethyl sulfoxide and the absorbance of the blue color was measured at $490 \mathrm{~nm}$ using a microplate reader.

Preparations of nuclear proteins. Cells $\left(1 \times 10^{7}\right.$ cells $\left./ \mathrm{ml}\right)$ were harvested, washed with ice-cold phosphate-buffered saline (PBS), centrifuged and resuspended in ice-cold isotonic buffer A [10 mM HEPES (pH 7.9), $10 \mathrm{mM} \mathrm{KCl,} 1.5 \mathrm{mM}$ $\mathrm{MgCl}_{2}, 0.5 \mathrm{mM}$ dithiothreitol (DTT) and $0.5 \mathrm{mM}$ phenylmethanesulfonyl fluoride (PMSF)]. Following incubation in an ice bath for $15 \mathrm{~min}$, the cells were centrifuged at $16,000 \mathrm{x} \mathrm{g}$ for $5 \mathrm{~min}$ at $4^{\circ} \mathrm{C}$. The cells were then resuspended in ice-cold buffer C [20 mM HEPES (pH 7.9), 20\% glycerol, $0.4 \mathrm{M} \mathrm{NaCl}$, $1.5 \mathrm{mM} \mathrm{MgCl}, 0.2 \mathrm{mM}$ EDTA, $0.5 \mathrm{mM}$ DTT and $0.5 \mathrm{mM}$ PMSF], which was followed by incubation at $4^{\circ} \mathrm{C}$ for $40 \mathrm{~min}$. Following vortex-mixing, the resulting suspension was centrifuged at $16,000 \mathrm{x} \mathrm{g}$ for $10 \mathrm{~min}$ at $4^{\circ} \mathrm{C}$, and the supernatant was stored at $-80^{\circ} \mathrm{C}$. The protein content was determined by bicinchoninic protein assay reagent.

Reverse transcription-polymerase chain reaction $(R T-P C R)$. Total RNA was isolated from cells using TRIzol-reagent (Invitrogen Life Technologies, Carlsbad, CA, USA) and quantified by ultraviolet absorption at 260 and $280 \mathrm{~nm}$. RT-PCR was performed according to the manufacturer's instructions. According to GenBank, the RT-PCR primers were designed as follows: MMP-2 sense, 5'-ACCTGTCACTCCGGAGATCTGCAA-3' and antisense, 5'-TCACGCTCTTGAGACTTTGGTTCT-3'. The PCR conditions were as follows: 30 cycles of $94^{\circ} \mathrm{C}$ for $30 \mathrm{sec}$; $55^{\circ} \mathrm{C}$ for $30 \mathrm{sec}$; and $72^{\circ} \mathrm{C}$ for $45 \mathrm{sec}$. The amplified products were visualized by $1.5 \%$ agarose gel electrophoresis, stained with ethidium bromide and images were then captured under ultraviolet light. Densitometric analysis of the different observations was performed using Quantity One Software (Bio-Rad, Hercules, CA, USA). The quantity of each transcript was normalized against GAPDH.

Western blot analysis. VSMCs were harvested at the indicated time points and lysed into lysis buffer. Total proteins $(50 \mu \mathrm{g}$ per well) were separated by $10 \%$ SDS-PAGE and electrophoretically transferred to nitrocellulose membranes. Following blocking for $1 \mathrm{~h}$ with $5 \%$ skimmed milk in Tris-buffered saline (TBS; $10 \mathrm{mM}$ Tris and $150 \mathrm{mM} \mathrm{NaCl}$ ), the membrane was washed three times for 15 min each with TBS Tween-20 buffer (10 mM Tris, $150 \mathrm{mM} \mathrm{NaCl}$ and $0.1 \%$ Tween-20). Immunoreactive bands were visualized using horseradish peroxidase-conjugated secondary antibodies and an enhanced chemiluminescence (ECL) western blotting detection kit (GE Healthcare, Little Chalfont, UK). The bands were visualized using the ECL system, and the band density was determined using Image $\mathbf{J}$ software. All the antibodies were purchased from the Beyotime Institute of Biotechnology (Shanghai, China).

Gelatin zymography. Enzymatic activity levels of MMP-2 were assessed by gel zymographic analysis (10). The protein content of the samples was measured by the colorimetric method using serum albumin as the standard. In total, 50- $\mu \mathrm{g}$ samples of proteins from the VSMC lysate were loaded on an $11 \%$ SDS-PAGE gel containing $0.1 \%$ gelatin for electrophoresis in a $4^{\circ} \mathrm{C}$ cold room. Subsequently, the gels were incubated with collagenase buffer for $16 \mathrm{~h}$ at $37^{\circ} \mathrm{C}$, stained with $0.25 \%$ Coomassie Brilliant Blue, destained with $30 \%$ isopropanol in $10 \%$ acetic acid and visualized.

Cell migration assay. The invasion of VSMCs through the extracellular matrix was determined using a commercial cell invasion assay kit (Chemicon International, Temecula, CA, USA), as described in a previous study (11). VSMCs were resuspended in conditioned medium that had been collected following pretreatment with curcumin and TNF- $\alpha$-treated cells for $23 \mathrm{~h}$, and were added to the upper components of the migration chamber. Next, a 500- $\mu 1$ sample of the same conditioned medium was added to the lower compartment of the migration chamber. Cells without TNF- $\alpha$-treated conditioned medium served as the control. The migration chambers were incubated at $37^{\circ} \mathrm{C}$ for $24 \mathrm{~h}$ in an atmosphere of $5 \% \mathrm{CO}_{2}$. Following incubation, the inserts were removed from the wells and the cells on the upper side of the filter were removed using cotton swabs. The filters were fixed and stained according to the manufacturer's instructions. Next, $100 \mu \mathrm{l}$ dye mixture was transferred to a 96-well plate and the optical density was measured at $560 \mathrm{~nm}$.

Measurement of reactive oxygen species (ROS). Prior to chemical treatment, the cells were incubated in culture medium containing $30 \mu \mathrm{M}$ 2',7-dichlorofluorescein (DCF; Beyotime Institute of Biotechnology, Shanghai, China), a fluorescent dye, for $30 \mathrm{~min}$ to establish a stable intracellular level of the probe. Subsequently, the cells were washed with PBS, removed from the Petri dishes by scraping and evaluated for DCF fluorescence intensity. This was used as an index of the intracellular levels of ROS. The fluorescent DCF was detected using a laser scanning confocal microscope (TCS-NT; Leica Microsystems, Heidelberg, Germany) with excitation and emission wavelengths of 488 and $520 \mathrm{~nm}$, respectively. The cell number in each sample was counted and utilized to normalize the fluorescence intensity of DCF.

Statistical analysis. Data are expressed as the mean \pm standard deviation of three assays. Statistical analysis was conducted using one-way analysis of variance and $\mathrm{P}<0.05$ was considered to indicate a statistically significant difference. All statistical 


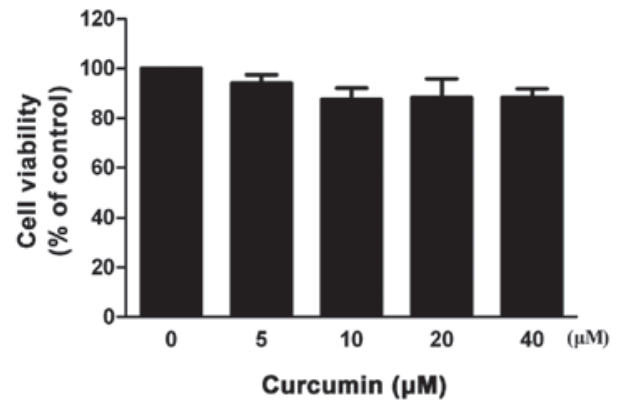

Figure 1. Cell toxicity of curcumin. The cytotoxic effect of curcumin in VSMCs was determined by an MTT assay. Data are expressed as the mean \pm standard deviation of three independent experiments. VSMCs, vascular smooth muscle cells; MTT, methylthiazolyl tetrazolium.

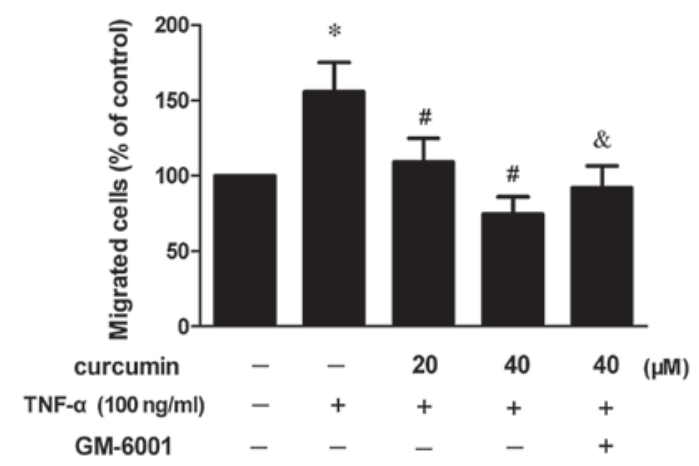

Figure 2. Curcumin inhibits TNF- $\alpha$-stimulated migration in VSMCs. VSMCs were resuspended in a conditioned medium following treatment with TNF- $\alpha$ for $23 \mathrm{~h}$, and were added to the upper components of the migration chamber in the presence of 20 and $40 \mu \mathrm{M}$ curcumin (or $10 \mu \mathrm{M}$ GM-6001). ${ }^{*} \mathrm{P}<0.05$, vs. control group; ${ }^{\text {}} \mathrm{P}<0.05$, vs. TNF- $\alpha$-treated group; ${ }^{\&} \mathrm{P}<0.05$, vs. TNF- $\alpha+$ curcumin group. Data are expressed as the mean \pm standard deviation of three independent experiments. VSMCs, vascular smooth muscle cells; TNF, tumor necrosis factor.

analyses were performed using SPSS 13.0 software (SPSS, Inc., Chicago, IL, USA).

\section{Results}

Assessment of cell toxicity of curcumin. The MTT assay was performed to evaluate the cytotoxicity of curcumin on VSMCs. As shown in Fig. 1, curcumin did not exhibit a dose-dependent $(0-40 \mu \mathrm{M})$ cytotoxic effect in VSMCs. According to the results of the MTT assay, curcumin concentrations of 20 and $40 \mu \mathrm{M}$ were selected for all the following experiments.

Curcumin inhibits TNF- $\alpha$-stimulated migration in VSMCs. To investigate the effect of curcumin on the migration ability of VSMCs, a cell migration assay was performed. As shown in Fig. 2, the migration of VSMCs increased following treatment with $100 \mathrm{ng} / \mathrm{ml} \mathrm{TNF}-\alpha$, whereas 20 and $40 \mu \mathrm{M}$ curcumin reduced cell migration in TNF- $\alpha$-induced VSMCs and a statistically significant difference was observed $(\mathrm{P}<0.05)$. When VSMCs were pretreated with an MMP inhibitor (GM-6001), the inhibitory effect was partly diminished.

Curcumin inhibits TNF- $\alpha$-induced MMP-2 expression and activity in VSMCs. VSMCs were treated with $100 \mathrm{ng} / \mathrm{ml} \mathrm{TNF-} \alpha$ in the presence or absence of various concentrations of curcumin.
A

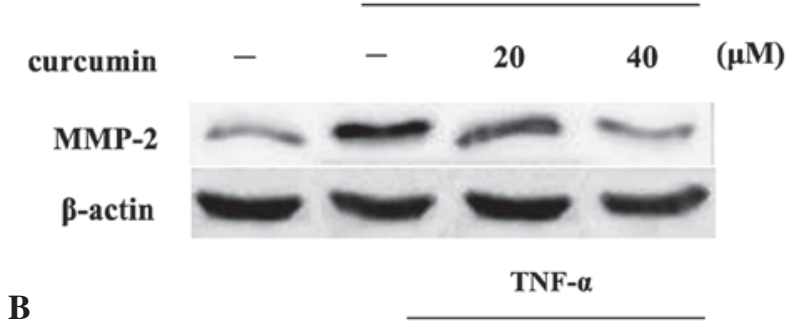

B

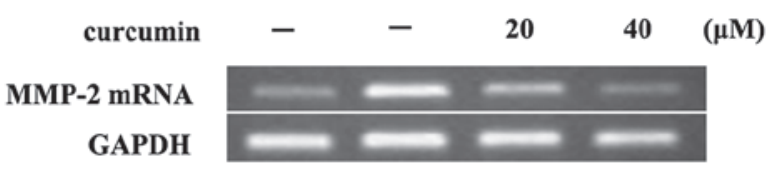

C

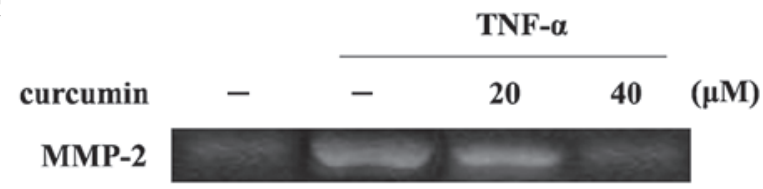

D

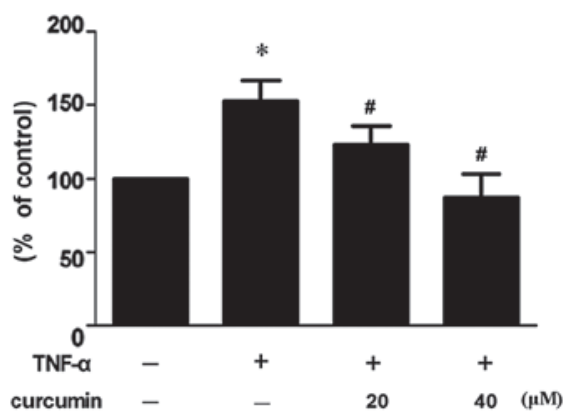

Figure 3. Curcumin inhibits TNF- $\alpha$-induced MMP-2 expression and activity in VSMCs. VSMCs were pretreated with curcumin (20 or $40 \mu \mathrm{M}$ ) for $1 \mathrm{~h}$ and exposed to $100 \mathrm{ng} / \mathrm{ml} \mathrm{TNF}-\alpha$ for an additional $23 \mathrm{~h}$. Following treatment, the (A) protein expression, (B) mRNA expression and (C) activity levels of MMP-2 were assessed by western blot analysis, RT-PCR and gelatin zymography, respectively. (D) Densitometric analysis was conducted with Image $\mathbf{J}$ software to quantify the gelatin zymography data. ${ }^{*} \mathrm{P}<0.05$, vs. control group; ${ }^{\#} \mathrm{P}<0.05$, vs. TNF- $\alpha+$ curcumin group. Data are expressed as the mean \pm standard deviation of three independent experiments. VSMCs, vascular smooth muscle cells; TNF, tumor necrosis factor; MMP, matrix metalloproteinase; RT-PCR, reverse transcription polymerase chain reaction.

Compared with TNF- $\alpha$ alone, 20 and $40 \mu \mathrm{M}$ curcumin significantly reduced MMP-2 expression and activity levels $(\mathrm{P}<0.05$; Fig. 3). Treatment with $40 \mu \mathrm{M}$ curcumin was more effective at decreasing the levels of protein expression and activity of MMP-2 when compared with $20 \mu \mathrm{M}$ curcumin treatment.

Curcumin suppresses TNF- $\alpha$-induced MMP-2 expression in VSMCs via the nuclear factor $(N F)-\kappa B$ pathway. In order to further investigate whether the NF- $\kappa \mathrm{B}$ signaling pathway is involved in the inhibitory effect of curcumin on the TNF- $\alpha$-induced expression of MMP-2, cells were pretreated with an inhibitor of NF- $\kappa B$ (BAY11-7082). The results revealed that the inhibitory effect was partly eliminated (Fig. 4). In addition, the effect of curcumin on the p65 subunit, induced by TNF- $\alpha$, was also determined. As a result, TNF- $\alpha$ was found to increase the expression of the p65 subunit in the nucleus, but this increase was inhibited when the cells had been preincubated with curcumin (Fig. 5). 
A

B
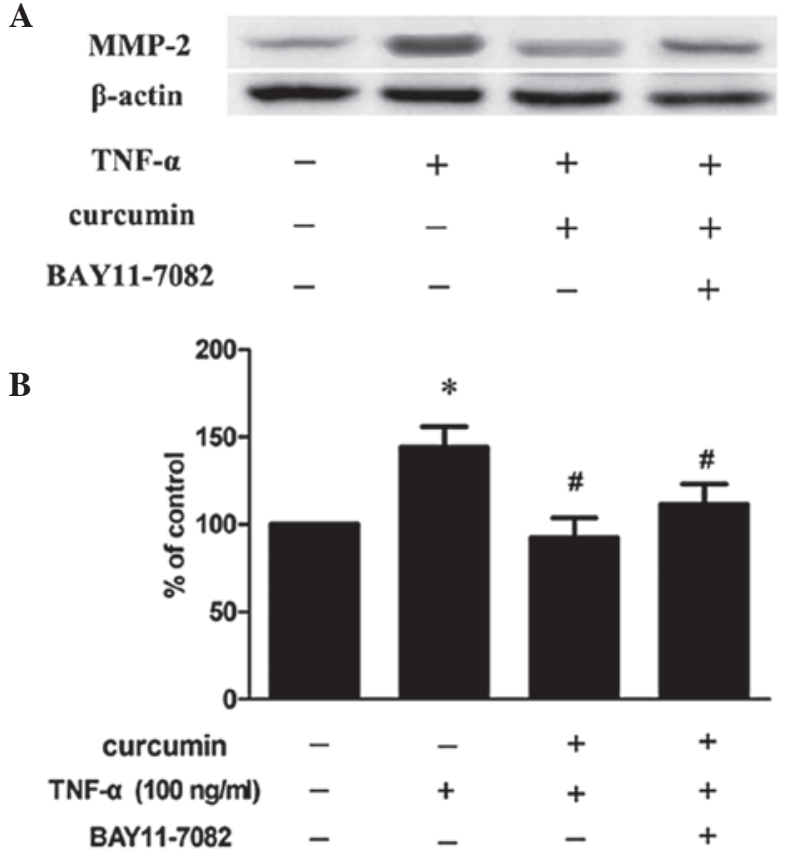

Figure 4. Curcumin suppresses TNF- $\alpha$-induced MMP-2 expression. (A) VSMCs were pretreated with $40 \mu \mathrm{M}$ curcumin and $10 \mu \mathrm{M}$ BAY11-7082 for $1 \mathrm{~h}$ and exposed to $100 \mathrm{ng} / \mathrm{ml} \mathrm{TNF}-\alpha$ for an additional $23 \mathrm{~h}$. Following treatment, the protein expression levels of MMP-2 were determined by western blot analysis. (B) Densitometric analysis was conducted with Image J software to quantify the western blot data. ${ }^{*} \mathrm{P}<0.05$, vs. control group; ${ }^{\text {"}} \mathrm{P}<0.05$, vs. TNF- $\alpha$-treated group. Data are expressed as the mean \pm standard deviation of three independent experiments. VSMCs, vascular smooth muscle cells; TNF, tumor necrosis factor; MMP, matrix metalloproteinase.

Curcumin prevents TNF- $\alpha$-induced ROS generation. Increased ROS generation was observed in VSMCs that had been stimulated with TNF- $\alpha$, whereas the inhibitory effect was significantly blocked by pretreatment with curcumin (Fig. 6; P<0.05).

\section{Discussion}

VSMC migration evidently plays a critical role in the pathophysiology of several prominent cardiovascular disease states, including atherosclerosis and restenosis $(12,13)$. Previous studies have shown that the MMP system may be a potential therapeutic target for the treatment of restenosis or atherosclerosis since the MMP system plays a role in VSMC migration and neointima formation following vascular injury (14). In the present study, the inhibitory effect of curcumin on TNF- $\alpha$-induced VSMC migration was investigated, as well as the possible mechanisms involved. Curcumin was found to inhibit the TNF- $\alpha$-stimulated migration of VSMCs, which is consistent with a previous study (15). In addition, administration of an MMP inhibitor (GM-6001) was shown to partly diminish the inhibitory effect, indicating that MMP-2 may play an important role in this process.

Accumulating evidence has indicated that gelatinase MMP-2 plays a pivotal role in the initiation and progression of atherosclerotic lesions. MMP-2 is constitutively expressed in VSMCs in normal arteries (9), and MMP-2 expression and activity levels may contribute to the pathogenesis of atherosclerosis by facilitating the migration of VSMCs (16). Therefore,

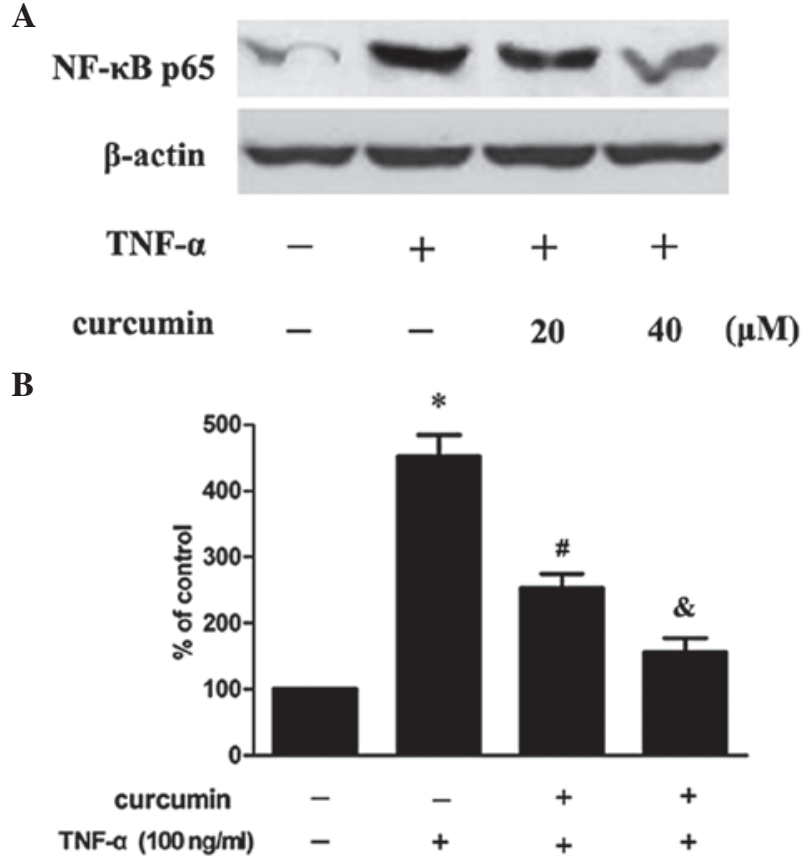

Figure 5. Effects of curcumin on TNF- $\alpha$-induced NF- $\kappa \mathrm{B}$ p65 expression. (A) VSMCs were pretreated with curcumin for $1 \mathrm{~h}$ and exposed to $100 \mathrm{ng} / \mathrm{ml}$ TNF- $\alpha$ for an additional 23 h. Following treatment, NF- $\kappa$ B p65 expression levels were determined by western blot analysis. (B) Densitometric analysis was conducted with Image $\mathbf{J}$ software to quantify the western blot analysis data. ${ }^{*} \mathrm{P}<0.05$, vs. control group; ${ }^{~} \mathrm{P}<0.05$, vs. TNF- $\alpha$-treated group; ${ }^{\circledR} \mathrm{P}<0.05$, vs. TNF- $\alpha+$ curcumin group. Data are expressed as the mean \pm standard deviation of three independent experiments. VSMCs, vascular smooth muscle cells; TNF, tumor necrosis factor; NF, nuclear factor.

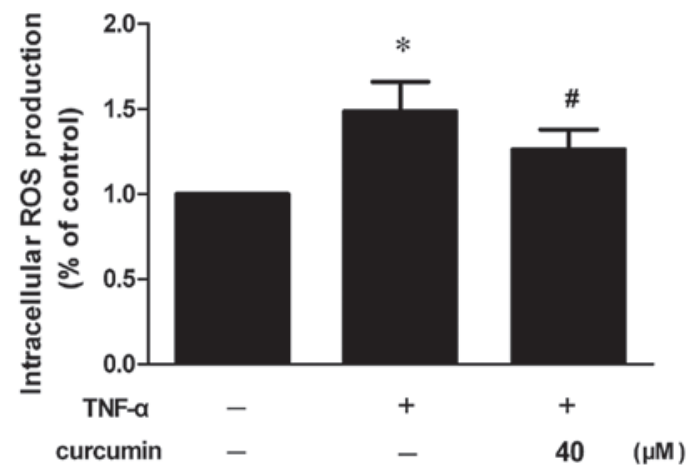

Figure 6. Curcumin prevents TNF- $\alpha$-induced ROS generation in VSMCs VSMCs were pretreated with $40 \mu \mathrm{M}$ curcumin for $1 \mathrm{~h}$ and induced by $100 \mathrm{ng} / \mathrm{ml}$ TNF- $\alpha$ for $23 \mathrm{~h}$. ${ }^{*} \mathrm{P}<0.05$, vs. control group; ${ }^{\#} \mathrm{P}<0.05$, vs. TNF- $\alpha$-treated group. Data are expressed as the mean \pm standard deviation of three independent experiments. VSMCs, vascular smooth muscle cells; TNF, tumor necrosis factor; ROS, reactive oxygen species.

the inhibitory effect of curcumin on the TNF- $\alpha$-induced expression and activity of MMP-2 was further investigated. Subsequently, curcumin was demonstrated to significantly inhibit TNF- $\alpha$-induced MMP-2 expression and activity, which indicated that MMP-2 is possibly involved in the inhibitory effect of curcumin on TNF- $\alpha$-induced cell migration.

TNF- $\alpha$ is one of the major inflammatory cytokines that mediates a wide range of biological responses, including inflammation, infection, injury and apoptosis (17). The effects of TNF- $\alpha$ are initiated by binding to its receptors, which causes 
the activation of two major transcription factors, AP-1 and $\mathrm{NF}-\kappa \mathrm{B}$. This in turn induces the expression of genes involved in inflammatory responses and apoptosis (18). A previous study also demonstrated that inflammatory cytokines, including TNF- $\alpha$, may induce the expression of the genes that encode MMPs (19). Thus, the present study provides new evidence that TNF- $\alpha$ enhances MMP-2 expression and activity in cultured VSMCs, and to the best of our knowledge, the present study shows for the first time that curcumin significantly inhibits TNF- $\alpha$-induced MMP-2 expression and activity. Previous studies have indicated that transcriptional regulation involving $\mathrm{NF}-\kappa \mathrm{B}$ activation has been implicated in the TNF- $\alpha$-induced activation of VSMCs (20). A key component of MMP expression is the redox-sensitive transcription factor NF- $\kappa \mathrm{B}(21)$.

Therefore, to further investigate whether NF- $\kappa \mathrm{B}$ contributes to the regulatory effect of curcumin on $\mathrm{TNF}-\alpha$-induced MMP-2 expression and activity, the cells were pretreated with BAY11-7082 (an NF- $\kappa$ B inhibitor) and curcumin prior to the addition of TNF- $\alpha$. The inhibitory effect was shown to be blocked by BAY11-7082, which indicated that NF- $\kappa \mathrm{B}$ is involved in this process.

In unstimulated cells, inactive $\mathrm{NF}-\kappa \mathrm{B}$ exists as a heterodimeric complex of the subunits, p50 and p65, that are complexed with the inhibitory protein, $\mathrm{I} \kappa \mathrm{B}$. Upon activation, phosphorylation of $\mathrm{I} \kappa \mathrm{B}$ results in its degradation, which is followed by the translocation of the liberated $N F-\kappa B$ to the nucleus where the dimer interacts with regulatory $\kappa \mathrm{B}$ elements in promoters and enhancers, thereby controlling gene transcription (22). Consistent with previous observations $(19,23,24)$, the present study also demonstrated that TNF- $\alpha$ activates NF- $\kappa \mathrm{B}$ in VSMCs. In addition, a key component of MMP expression is the redox-sensitive transcription factor NF- $\kappa \mathrm{B}$ (21). These results indicate that MMP expression, in response to TNF- $\alpha$, may be mediated by this transcription factor.

In the present study, curcumin was found to reduce TNF- $\alpha$-induced nuclear translocation of NF- $\kappa$ B p 65 in VSMCs. In addition, it was demonstrated that ROS play an essential role in NF- $\kappa \mathrm{B}$ activation via proinflammatory cytokines (TNF- $\alpha$ and interleukin-1 $\beta$ ) and lipopolysaccharide, two major components of innate immunity (25). The vast majority of studies concerning oxidant-induced NF- $\kappa \mathrm{B}$ activation have used $\mathrm{H}_{2} \mathrm{O}_{2}$ as a direct source of ROS. Schreck et al (26) were the first to demonstrate that the direct addition of $\mathrm{H}_{2} \mathrm{O}_{2}$ to a culture medium containing a subclone of Jurkat cells (Jurkat $\mathrm{JR}$ ) resulted in the activation of $\mathrm{NF}-\kappa \mathrm{B}$. Excess ROS activate the redox-sensitive transcription factor, $N F-\kappa B$, resulting in an increase in its activity and expression (27). The activation of $N F-\kappa B$ can be inhibited by antioxidants (28). Thus, the effect of curcumin on TNF- $\alpha$-induced ROS generation was investigated. Subsequently, TNF- $\alpha$-induced ROS generation and increased ROS generation was shown to be significantly blocked by pretreatment with curcumin. Therefore, the present study demonstrated that curcumin suppresses TNF- $\alpha$-stimulated MMP-2 expression and activity in VSMCs via the $\mathrm{NF}-\kappa \mathrm{B}$ pathway.

In conclusion, curcumin effectively inhibited the TNF- $\alpha$-induced migration of VSMCs. Levels of ROS production, MMP-2 activation and expression and nuclear translocation of $\mathrm{NF}-\kappa \mathrm{B}$ p 65 were also all reduced by curcumin pretreatment. These results demonstrate that curcumin suppresses TNF- $\alpha$-induced MMP-2 expression and activity in rat VSMCs via the $\mathrm{NF}-\kappa \mathrm{B}$ signaling pathway, thereby suppressing cell migration. Therefore, these observations support an emerging role of curcumin as a candidate for the treatment of atherosclerosis. In addition, the ROS/NF- $\kappa$ B pathway may be an additional potential therapeutic target for atherosclerosis-associated diseases.

\section{Acknowledgements}

The study was supported by a grant from the Affiliated Hospital of Luzhou Medical College (no. 12298).

\section{References}

1. Ross R: The pathogenesis of atherosclerosis: a perspective for the 1990s. Nature 362: 801-809, 1993.

2. Augé N, Maupas-Schwalm F, Elbaz M, Thiers JC, Waysbort A, Itohara S, Krell HW, Salvayre R and Nègre-Salvayre A: Role for matrix metalloproteinase-2 in oxidized low-density lipoprotein-induced activation of the sphingomyelin/ceramide pathway and smooth muscle cell proliferation. Circulation 110: 571-578, 2004

3. Aoyagi M, Yamamoto M, Azuma H, Nagashima G, Niimi Y, Tamaki M, Hirakawa K and Yamamoto K: Immunolocalization of matrix metalloproteinases in rabbit carotid arteries after balloon denudation. Histochem Cell Biol 109: 97-102, 1998.

4. Newby AC and Zaltsman AB: Fibrous cap formation or destruction - the critical importance of vascular smooth muscle cell proliferation, migration and matrix formation. Cardiovasc Res 41: 345-360, 1999.

5. Caird J, Napoli C, Taggart C, Farrell M and Bouchier-Hayes D: Matrix metalloproteinases 2 and 9 in human atherosclerotic and non-atherosclerotic cerebral aneurysms. Eur J Neurol 13: 1098-1105, 2006.

6. Ruby AJ, Kuttan G, Babu KD, Rajasekharan KN and Kuttan R: Anti-tumour and antioxidant activity of natural curcuminoids. Cancer Lett 94: 79-83, 1995.

7. Surh YJ: Anti-tumor promoting potential of selected spice ingredients with antioxidative and anti-inflammatory activities: a short review. Food Chem Toxicol 40: 1091-1097, 2002.

8. Goel A, Kunnumakkara AB and Aggarwal BB: Curcumin as 'Curecumin': from kitchen to clinic. Biochem Pharmacol 75: 787-809, 2008.

9. Kamimura M, Bea F, Akizawa T, Katus HA, Kreuzer J and Viedt C: Platelet-derived growth factor induces tissue factor expression in vascular smooth muscle cells via activation of Egr-1. Hypertension 44: 944-951, 2004.

10. Chang W, Lim S, Song H, Song BW, Kim HJ, Cha MJ, Sung JM, Kim TW and Hwang KC: Cordycepin inhibits vascular smooth muscle cell proliferation. Eur J Pharmacol 597: 64-69, 2008.

11. Yu YM and Lin HC: Curcumin prevents human aortic smooth muscle cells migration by inhibiting of MMP-9 expression. Nutr Metab Cardiovasc Dis 20: 125-132, 2010.

12. Schwartz SM, Heimark RL and Majesky MW: Developmental mechanisms underlying pathology of arteries. Physiol Rev 70: 1177-1209, 1990.

13. Owens GK: Regulation of differentiation of vascular smooth muscle cells. Physiol Rev 75: 487-517, 1995.

14. Lijnen HR: Plasmin and matrix metalloproteinases in vascular remodeling. Thromb Haemost 86: 324-333, 2001.

15. Sheu MJ, Lin HY, Yang YH, Chou CJ, Chien YC, Wu TS and Wu CH: Demethoxycurcumin, a major active curcuminoid from Curcuma longa, suppresses balloon injury induced vascular smooth muscle cell migration and neointima formation: An in vitro and in vivo study. Mol Nutr Food Res 57: 1586-1597, 2013.

16. Baeuerle PA and Baltimore D: I kappa B: a specific inhibitor of the NF-kappa B transcription factor. Science 242: 540-546, 1988.

17. Baud V and Karin M: Signal transduction by tumor necrosis factor and its relatives. Trends Cell Biol 11: 372-377, 2001.

18. Barnes PJ and Karin M: Nuclear factor-kappaB: a pivotal transcription factor in chronic inflammatory diseases. N Engl J Med 336: 1066-1071, 1997. 
19. Lee B and Moon SK: Resveratrol inhibits TNF-alpha-induced proliferation and matrix metalloproteinase expression in human vascular smooth muscle cells. J Nutr 135: 2767-2773, 2005.

20. McKellar GE, McCarey DW, Sattar N and McInnes IB: Role for TNF in atherosclerosis? Lessons from autoimmune disease. Nat Rev Cardiol 6: 410-417, 2009.

21. Newby AC: Metalloproteinase expression in monocytes and macrophages and its relationship to atherosclerotic plaque instability. Arterioscler Thromb Vasc Biol 28: 2108-2114, 2008.

22. Hayden MS and Ghosh S: Signaling to NF-kappaB. Genes Dev 18: 2195-2224, 2004.

23. Kim HS, Kim HJ, Park KG, Kim YN, Kwon TK, Park JY, Lee KU, Kim JG and Lee IK: Alpha-lipoic acid inhibits matrix metalloproteinase-9 expression by inhibiting NF-kappaB transcriptional activity. Exp Mol Med 39: 106-113, 2007.

24. Kim CH and Moon SK: Epigallocatechin-3-gallate causes the p21/WAF1-mediated G(1)-phase arrest of cell cycle and inhibits matrix metalloproteinase-9 expression in TNF-alpha-induced vascular smooth muscle cells. Arch Biochem Biophys 435: 264-272, 2005
25. Gloire G, Legrand-Poels S and Piette J: NF-kappaB activation by reactive oxygen species: fifteen years later. Biochem Pharmacol 72: 1493-1505, 2006.

26. Schreck R, Rieber P and Baeuerle PA: Reactive oxygen intermediates as apparently widely used messengers in the activation of the NF-kappa B transcription factor and HIV-1. EMBO J 10: 2247-2258, 1991.

27. Janssen-Heininger YM, Poynter ME and Baeuerle PA: Recent advances towards understanding redox mechanisms in the activation of nuclear factor kappaB. Free Radic Biol Med 28: 1317-1327, 2000.

28. Bar-Shai M, Carmeli E, Ljubuncic P and Reznick AZ: Exercise and immobilization in aging animals: the involvement of oxidative stress and NF-kappaB activation. Free Radic Biol Med 44: 202-214, 2008. 